\title{
Nuoren työvoiman asema Suomen työmarkkinoilla
}

\author{
Valtiot. tri TERHO PULKKINEN
}

Työmarkkinantutkimustoimisto

Viime aikoina useassa eri yhteydessä esille tullut ns. suurten ikäluokkien kysymys on kääntänyt katseet nuoren työvoiman ongelmiin aivan toisella tavalla kuin aikaisempina vuosikymmeninä. Väestönkehitys on johtanut siihen, että nuorimmat työikäiset ikäluokat kasvavat poikkeuksellisen runsaasti 1960-luvulla ja erityisesti sen alkupuolella. Kun toisaalta työvoimasta poistuvien määrä on tavallista suurempi, on yhteiskunnan suoritettavaksi annettu vaativa tehtäväryhmä, johon kuuluu ammattitaitoisen työvoiman jälkikasvun turvaaminen eli nuoren työvoiman kouluttaminen tuotantoelämän palvelukseen ja sen sijoittaminen työmarkkinoille mahdollisimman tarkoituksenmukaisesti.

\section{Nuoren työvoiman tarjonta}

Työikäisen (15-64-vuotiaan) väestön ${ }^{1}$ ja työvoiman² lisääntymisestä on esitetty ennusteita useassakin yhteydessä. Palautettakoon tässä mieleen kuitenkin vielä kertauksen vuoksi koko työikäisen ja 15 -24-vuotiaan väestön kasvu vuosina 1960 -70 (taulu 1). Työikäinen väestö lisääntyy tällöin poikkeuksellisen nopeasti eli vuosikymmenen alkupuolella peräti 47000 henkeä ja jälkipuoliskollakin vielä 31000 henkeä keskimäärin vuodessa. Erityisen no-

1 Tor Hartman. Väestönkehityksen ennuste vuoteen 1975 saakka. Tilastokatsauksia $1959,4$.

2 Aarno Strömmer. Väestönkehitys ja työvoimavarat Suomessa vuosina 1950-70. Valtakunnansuunnittelutoimiston julkaisusarja A: 5. Helsinki 1959 sekä Terho Pulkkinen. Väestön ja työvoiman kehitys. Talousohjelmakomitean osamietintö II. Liite N:o 1. Helsinki 1960. peasti kuitenkin kasvavat nuorimmat työikäiset ikäluokat. Nousu jatkuu voimakkaana aina 1960 -luvun viimeisiin vuosiin saakka. Juuri parhaillaan elämme voimakkaimman lisäyksen aikaa ja 15-24vuotiaiden määrä kasvoi vuodesta 1960 vuoteen 1961 yli 37000 henkilöä, mikä on suurin vuotuinen lisäys kuluvalla vuosikymmenellä. Kaiken kaikkiaan nämä ikäluokat lisääntyvät 1960-luvun aikana noin neljännesmiljoonalla.

Suuri osa työikäisen väestön nuorimpiin kerroksiin kuuluvista henkilöistä käyttää kuitenkin aikansa koulunkäyntiin ja opiskeluun ja tulee työvoimaan vasta sitten, kun ammattitaidon hankkimiseen käytettävä ikävaihe on sivuutettu. Eri maissa

T a ulu 1. Koko työikäisen (15-64-vuotiaan) ja 15-24-vuotiaan väestön muutos vuosina 1960-70. Lähde: Tor Hartman, m.k.

\begin{tabular}{l|l|c|c|c}
\hline & \multicolumn{4}{|c}{ I k ä l u o k k a } \\
\cline { 2 - 5 } Vuosi & $15-64$ & $15-24$ & $15-64$ & $15-24$ \\
& & Lisäys & tai vä- & \multicolumn{2}{c}{ Indeksi } \\
\cline { 2 - 5 } & hennys $(-)$ & $1959=100$ \\
& 1000 henkilöä & & \\
& \multicolumn{4}{|c}{} \\
1960 & 40.2 & 26.5 & 101.5 & 104.0 \\
1961 & 51.6 & 37.4 & 103.3 & 109.6 \\
1962 & 52.0 & 35.9 & 105.3 & 115.0 \\
1963 & 48.2 & 32.1 & 107.0 & 119.8 \\
1964 & 43.9 & 26.7 & 108.6 & 123.8 \\
1965 & 39.0 & 32.4 & 110.0 & 128.7 \\
1966 & 33.0 & 4.8 & 111.3 & 129.4 \\
1967 & 34.6 & 31.6 & 112.5 & 134.2 \\
1968 & 30.7 & 15.8 & 113.6 & 136.6 \\
1969 & 27.1 & 11.9 & 114.6 & 138.3 \\
1970 & 27.6 & -4.7 & 115.6 & 137.6 \\
\hline
\end{tabular}


Ta ulu 2. Työintensiteetti ikäluokittain v. 1950 ja tammi-helmikuun vaihteessa v. 1961. Prosenttia kunkin ikäluokan koko väestöstä. Lähde: Toini Ristimäki. Työintensiteetin kehitys Suomessa vv. 195061. Kansallis-Osake-Pankin Kuukausikatsaus 1961, 11.

\begin{tabular}{l|c|c|c|c}
\hline & \multicolumn{2}{|c|}{ Miehet } & \multicolumn{2}{c}{ N a iset } \\
\cline { 2 - 4 } $\begin{array}{l}\text { Ikä- } \\
\text { ryhmä }\end{array}$ & 1950 & 1951 & 1950 & 1951 \\
\cline { 2 - 4 } & \multicolumn{3}{|c}{$\%$} \\
\hline
\end{tabular}

\begin{tabular}{llclc}
$15-19$ & 74.2 & 59.6 & 53.4 & 44.6 \\
$20-24$ & 90.4 & 71.1 & 64.4 & 64.8 \\
$25-29$ & 94.9 & 91.3 & 56.8 & 54.3 \\
$30-34$ & 97.2 & 94.4 & 57.0 & 65.6 \\
$35-44$ & 97.7 & 93.4 & 59.9 & 66.1 \\
$45-54$ & 96.6 & 89.2 & 59.9 & 65.1 \\
$55-59$ & 93.5 & 81.3 & 52.6 & 53.2 \\
$60-64$ & 86.6 & 72.2 & 42.0 & 40.5 \\
$65+$ & 56.7 & $(22.1)$ & 20.6 & $(6.0)$ \\
\hline
\end{tabular}

suoritetuissa tutkimuksissa on voitu havaita, että työhönosallistumisen eli työintensiteetin pääsuunta on laskeva, mikä johtuu työhönosallistumisen vähenemisestä lähinnä nuorimmissa ja vanhimmissa ikäluokissa. Elintason kohotessa koulunkäynti yleistyy, koulutukseen käytetty aika pitenee ja vanhimmat ikäluokat vetäytyvät eläkeiän alentuessa entistä aikaisemmin pois työvoimasta. Tähän saakka meillä Suomessa ei ole ollut mahdollista tutkia työintensiteetin muutosta ikäluokittain, koska työintensiteettiluvut ovat olleet tiedossa vain vuodelta 1950 . On voitu vain olettaa, että nimenomaan nuorimmissa ikäluokissa työhönosallistumisen on täytynyt huomattavasti alentua, koska koulunkäynti ja opiskelu maassamme on selvästi yleistynyt. Onhan esimerkiksi oppikoulujen oppilasmäärä kymmenessä vuodessa noin kaksinkertaistunut. Työmarkkinatutkimustoimiston suorittaman jatkuvan työvoimatutkimuksen tuloksista voidaan nyt kuitenkin laskea työintensiteettilukuja ikäluokittain vuodelta 1961 ja verrata näitä kymmentä vuotta aikaisempiin väestölaskennan tietoihin. ${ }^{1}$ Työvoi-

1 Toini Ristimäki. Työintensiteetin kehitys Suomessa vv. 1950-61. KansallisOsake-Pankin Kuukausikatsaus 1961, 11. maan työvoimatutkimuksessa luetaan kaikki työlliset ja työttömät, jolloin työllisillä tarkoitetaan henkilöitä, joilla on työpaikka, riippumatta siitä, ovatko he laskentaviikolla olleet työssä vai tilapäisesti poissa työpaikastaan. Työvoimaan kuulumattomiksi taas luetaan koululaiset, opiskelijat, asevelvolliset, ao. viikolla yksinomaan omaa kotitaloustyötä tekevät perheenemännät, pysyvästi tai pitkäaikaisesti työkyvyttömät, eläkkeellä olevat sekä laitoshoidokit.

Työvoimaan kuuluvuutta on työvoimatutkimuksen mukaan tarkastelu toistaiseksi vain yhdeltä viikolta, joka päättyi 4 . 2. 1961. Muutenkaan nämä tiedot eivät ole täysin vertailukelpoisia väestölaskennan lukujen kanssa, sillä on todettu, että mitä pienemmän aikayksikön (kuukauden, viikon, päivän) työvoimasta on kysymys, sitä pienemmäksi se pyrkii tulemaan koko vuoden työvoimaan verrattuna..2 Väestölaskennan ammatissa toimivaan väestöön tulisivat täten luetuksi monet sellaiset henkilöt, jotka työvoimatutkimuksessa jätetään laskentaviikolla työvoiman ulkopuolelle. On myös syytä muistaa, että työintensiteetti on ilmeisesti riippuvainen yleisestä taloudellisesta tilanteesta, niin että noususuhdanteen aikana työvoimaan kuuluvuus pyrkii lisääntymään. Runsas työvoiman kysyntä sekä siitä syystä kohonnut palkka- ja ansiotaso houkuttelevat työvoimaan myös sellaisia henkilöitä, jotka muulloin eivät osallistu ansiotyöhön. Laskusuhdanteen aikana työvoiman kysynnän vähentyessä tapahtuu taas vastaavasti vapaaehtoista vetäytymistä työvoimasta. Pääasiassa tämä koskenee omaa kotitaloustyötä tekeviä perheenemäntiä, mutta kesäisin sekä muina oppilaitosten loma-aikoina myös niitä nuorimpiin työikäisiin ikäluokkiin kuuluvia henkilöitä, jotka käyttävät osan ajastaan koulunkäyntiin ja opiskeluun.

Työvoimatutkimuksen tulokset vahvistavat sitä käsitystä, että kuluneen 11 vuoden aikana työintensiteetti on merkittävästi alentunut etenkin miesten nuorim-

2 Lauri Heikinheimo. Metsätyövoiman tutkimusmenetelmä. Acta Forestalia Fennica 63. Helsinki 1954. 
missa työikäisissä ikäluokissa (taulu 2). Aleneminen on huomattavin ikäryhmässä 20-24 vuotta ja selvästi suurempi kuin ikäryhmässä $15-19$ vuotta. Tällöin näyttää siltä, että ensiksi mainitussa ryhmässä skoulutusintensiteetti» on vuoteen 1950 verrattuna kasvanut enemmän kuin jälkimmäisessä. Tämä on merkkinä paitsi ammattikoulutuksen yleistymisestä myös koulutusajan pitenemisestä, minkä on tehnyt tarpeelliseksi työvoiman laatuvaatimusten kasvaminen jatkuvasti teknillistyvän ja monimutkaistuvan tuotantotoiminnan piirissä.

Ei ole syytä uskoa, että edellä todettu kehitys olisi päätepisteessään, vaan että työintensiteetin suunta nuorten ikäluokkien osalta lienee edelleen aleneva. Tällaiseen käsitykseen johtaa se, että $\mathrm{mm}$. Norjassa 15-19-vuotiaiden nuorukaisten työintensiteetti on laskenut $72.2 \%$ :sta vuonna 1950 jopa $51.2 \%$ :iin vuonna 1961 eli siis huomattavasti alemmaksi kuin Suomessa. ${ }^{1}$

\section{Nuoren tyồvoiman rakenne}

Työintensiteetin voimakkaasta alenemisesta huolimatta kuului siis 15-24-vuotiaista miehistä vielä n. $60-71 \%$ ja naisista vastaavasti 45-65\% työvoimaan vuoden 1961 alussa. Jatkuvan työvoimatutkimuksen tulosten avulla on myös mahdollista tarkastella, miten tämä nuorin työvoima jakaantuu elinkeinoittain (taulu 3 ja kuva ).2 Työllisistä 15-19-vuotiaista miehistä oli 7. 1. 1961 päättyvällä viikolla yli puolet alkutuotannon (maa- ja metsätalouden) töissä, vajaa kolmannes jalostuksessa (teollisuus ja rakennustoiminta) ja vain $17 \%$ palveluksissa (kauppa, liikenne ja varsinaiset palvelukset). Tämä johtuu siitä, että alkutuotannon piirissä on runsaasti työtä, joka ei vaadi ammattitaitoa ja että metsätöissä

1 Sammandrag av den reviderte arbeidskraftprognose for 1960 og foreløpig prognose for 1961. Arbeidsmarkedet 1960,8 .

2 Toini Ristimäki. Työllisyys ikäluokittain ja elinkeinoittain tammikuussa 1961. Työmarkkinat 1961, 7-8. Moniste.
Ta u lu 3. Työllinen työvoima ikäluokittain ja elinkeinoittain tammikuussa 1961 jatkuvan työvoimatutkimuksen mukaan. Lähde: Toini Ristimäki. Työllisyys ikäluokittain ja elinkeinoittain tammikuussa 1961. Työmarkkinat 1961, 7-8. Moniste.

\begin{tabular}{|c|c|c|c|c|c|}
\hline \multirow{3}{*}{$\begin{array}{l}\text { Ikä- } \\
\text { ryhmä, } \\
\text { vuosia }\end{array}$} & \multirow{2}{*}{$\begin{array}{l}\text { Alku- } \\
\text { tuo- } \\
\text { tanto } \\
\text { (Maa- } \\
\text { ja met- } \\
\text { säta- } \\
\text { lous) }\end{array}$} & \multicolumn{2}{|c|}{ Jalostus } & \multirow{2}{*}{$\begin{array}{l}\text { Palve- } \\
\text { lukset, } \\
\text { (Kaup- } \\
\text { pa, lii- } \\
\text { kenne, } \\
\text { varsin. } \\
\text { palve- } \\
\text { lukset) }\end{array}$} & \multirow{2}{*}{$\begin{array}{l}\text { Yh- } \\
\text { teensä1 }\end{array}$} \\
\hline & & $\begin{array}{l}\text { Teolli- } \\
\text { suus, } \\
\text { kaivos- } \\
\text { toim., } \\
\text { käsityö }\end{array}$ & $\begin{array}{l}\text { Raken- } \\
\text { nustoi- } \\
\text { minta }\end{array}$ & & \\
\hline & \multicolumn{5}{|c|}{$\%$} \\
\hline
\end{tabular}

\begin{tabular}{|c|c|c|c|c|c|}
\hline & \multicolumn{5}{|c|}{ Miehet } \\
\hline & 52 & 24 & 7 & 17 & 10 \\
\hline $20-24$ & 29 & 31 & 16 & 24 & \\
\hline $25-29$ & 25 & 31 & 14 & 30 & \\
\hline $30-34$ & 29 & 28 & 14 & 28 & \\
\hline $35-44$ & 32 & 26 & 16 & 26 & \\
\hline $45-54$ & 39 & 22 & 14 & 24 & \\
\hline $55-59$ & 45 & 23 & 12 & 20 & \\
\hline \multirow[t]{2}{*}{$60-64$} & 49 & 21 & 9 & 19 & 10 \\
\hline & \multicolumn{4}{|c|}{$\mathrm{N}$ a ise $\mathrm{t}$} & \\
\hline $15-19$ & 25 & 14 & 1 & 59 & \\
\hline $20-24$ & 23 & 18 & 0 & 58 & \\
\hline $25-29$ & 27 & 17 & 0 & 55 & \\
\hline $30-34$ & 33 & 18 & 1 & 48 & 1 \\
\hline $35-44$ & 45 & 18 & 1 & 36 & \\
\hline $45-54$ & 47 & 18 & 1 & 33 & \\
\hline $55-59$ & 46 & 22 & 0 & 31 & \\
\hline $60-64$ & 52 & 15 & 1 & 31 & \\
\hline
\end{tabular}

1 Ryhmä »tuntematon» sisältyy yhteismäärään.

meillä käytetään runsaasti nuorta työvoimaa. Metsätyömaat sijaitsevat usein pitkien matkojen päässä, ja tavaksi on tullut, että niihin lähetetään nuorin työkuntoinen mies talostaan. Teollisuuden ja rakennustoiminnan sekä myös palvelusten työt sitävastoin vaativat useimmissa tapauksissa ammattitaitoa ja työkokemusta, jota työmarkkinoille tulevilla nuorukaisilla ei voi riittävästi olla. Iän ja työkokemuksen karttuessa siirrytään sitten vähitellen rakennustoiminnan ja teollisuuden töihin. Seuraavan ikäryhmän miehistä, 20-24vuotiaista, oli sitävastoin jo lähes puolet jalostuksen palveluksessa. Nuorten n a i st e n elinkeinojakautuma oli merkittävästi toisenlainen kuin miesten, sillä lähes $60 \%$ 


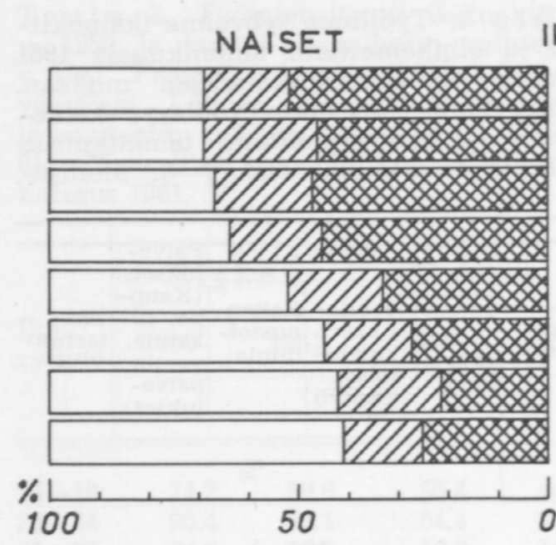

\section{Alkuotanto}

Ikäluokka

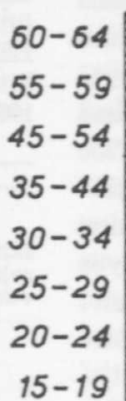

$15-19$

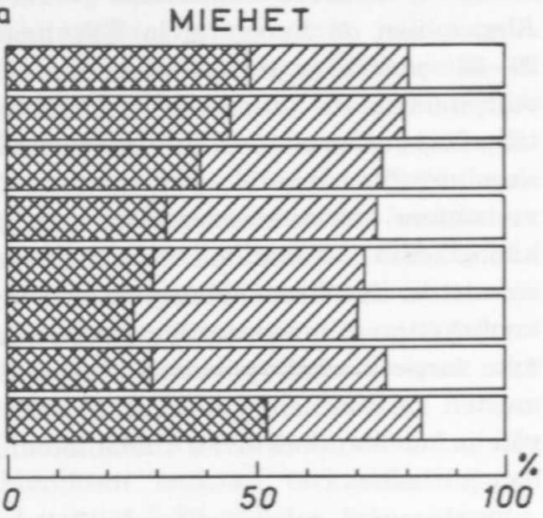

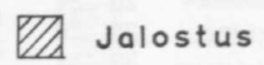

\section{Palvelukset}

Työllinen työvoima ikäluokittain ja elinkeinoittain tammikuussa 1961. Jatkuvan työvoimatutkimuksen mukaan.

sekä 15-19- että 20-24-vuotiaista naisista työskenteli palveluksissa. Nämä tunnetusti naisvaltaiset elinkeinot voivat siis ilmeisesti tarjota runsaasti työtä myös kouluttamattomalle tai vain vähän koulutusta ja työkokemusta saaneelle naistyövoimalle.

\section{Nuoren työvoiman kysyntä}

Yleisenä toteamuksena voidaan sanoa, että nuori työvoima on viimeksi kuluneen parin vuoden aikana voinut hyvin sijoittua työmarkkinoille. Tämän hetken näkemyksemme on kuitenkin optimismin sävyttämä johtuen siitä, että saamme yhä elää jo vuoden 1958 loppupuolella alkaneen taloudellisen nousukauden merkeissä. Työvoiman kysyntä on ollut runsasta ja työttömyysaste on supistunut niin pieneksi, että suoranaista työvoiman puutettakin on aika ajoin esiintynyt.

Jatkuvan työvoimatutkimuksen tulokset kuitenkin osoittavat, että tietyn suuruinen työttömyysriski on uhkaamassa nuorta työvoimaa myös runsaan työvoiman kysynnän vuosina. Vuonna 1960 keskimäärin viikkoa kohden laskettu miesten työttömyysaste oli nimittäin merkitsevästi suurempi ikäluokissa 15-20-vuotta kuin muissa ryhmissä, vanhimmat mukaan luettuna (taulu 4). Myös naisilla työttömien osuus ikäluokan koko työvoimasta oli suurin mainitussa nuorimmassa ikäryhmässä.

Nuoren työvoiman työttömyysastetta arvosteltaessa on muistettava, että etenkin ammattitaidottomilla ja vain vähän työkokemusta omaavilla nuorilla työsuhteet muodostuvat suurelta osalta tilapäisiksi ja lyhytaikaisiksi. Sopivaa työalaa ja työnantajaa etsiessään nuoret yleensäkin joutuvat usein vaihtamaan työpaikkaa, joten tästä johtuva kitkatyöttömyyden määrä pyrkii muodostumaan suureksi. Edelleen on huomattava, että jatkuva työvoimatutkimus rekisteröi luonnollisesti myös niiden henkilöiden työttömyyden, jotka ovat työhön käytettävissä vain tiettynä aikana vuodesta. Kun se osa koulua käyvästä ja opiskelevasta nuorisosta, joka haluaa osallistua ansiotyöhön, tulee yht'aikaisesti touko- ja kesäkuun vaihteessa työmarkkinoille, voi tällöin esiintyä työtilaisuuksien puutetta siitä huolimatta, että työvoiman kysyntä kasvaa yleensä samanaikaisesti. Koulujen päättymisen vaikutusta nuoren työvoiman lisäykseen osoit- 
takoon se, että työnvälitystoimistoissa alle 18-vuotiaiden osuus kaikista työnhakijoista oli vuosina 1955-59 toukokuussa keskimäärin $11 \%$ ja kesäkuussa $8 \%$, kun se vuoden alkukuukausina oli ainoastaan 2-4\%. ${ }^{1}$

Suhteellisen korkeasta työttömyysasteesta huolimatta voitaneen väittää, että työttömyys ei sittenkään ole vaikeinta nuorten keskuudessa, koska heidän työttömyytensä on otaksuttavasti lyhytaikaisempaa kuin vanhoilla, joiden on työttömäksi jouduttuaan vaikeampi kuin nuorten löytää uutta työpaikkaa, kuten Beveridge on suorittamassaan tutkimuksessa todennut. ${ }^{2}$

\section{Nuoren työvoiman työllistäminen kuluvalla vuosikymmenellä}

Koska noususuhdannevuonnakin nuoren työvoiman työttömyysaste on ollut huomattavan korkea, on selvää, että laskusuhdanteen aikana myös sen työttömyysriski yhä kasvaa. Laskukauden aiheuttaman työvoiman kysynnän vähenemisen seuraukset saattavat olla erityisen tuntuvia nuoren työvoiman osalta juuri kuluvalla vuosikymmenellä, jolloin nuoret ikäluokat ovat suurimmillaan. Saamme varautua siihen, että nousu- ja laskukaudet seuraavat toisiaan myös kuluvalla vuosikymmenellä, joten työvoiman kysyntää tasoittavaa työllisyyspolitiikkaa harjoitettaessa on erityisesti otettava huomioon nuoret ikäluokat ja niiden sijoittaminen tuotantoelämän palvelukseen. $\mathrm{Pi}-$ täen mielessä sen tunnetun tosiasian, että työttömyysriski on suurin ammattitaidottomilla työntekijöillä, on kaikenlaiselle koulutukselle nuorten ammattitaidon kohentamiseksi annettava ensisijainen merkitys. Tämä on välttämätöntä jo jatkuvan taloudellisen kasvunkin turvaamiseksi, mikä edellyttää, että tietämyksen ja taidon taso säilyy ja entisestään kohoaa työntekijäkunnan keskuudessa.

1 Terho Pulkkinen. Suurten ikäluokkien työllistämisongelma. Väestöntutkimuksen Vuosikirja VI - 1960.

2 William Beveridge. Full Employment in a Free Society. London 1953, s. 70.
Taulu 4. Työttömyysaste ikäluokittain vuonna 1960 kaksinkertaisin keskivirhein. Keskimäärin viikossa. Lähde: Toini Ristimäki. Työttömän työvoiman rakenne vuosina 1959 ja 1960. Työmarkkinat 1961, 6. Moniste.

\begin{tabular}{|c|c|c|c|}
\hline \multirow{2}{*}{$\begin{array}{l}\text { Ikä- } \\
\text { ryhmä }\end{array}$} & Miehet & $\mathrm{Na}$ ise $\mathrm{t}$ & $\begin{array}{l}\text { Molem- } \\
\text { mat su- } \\
\text { kupuolet }\end{array}$ \\
\hline & \multicolumn{3}{|c|}{$\%$} \\
\hline $15-20$ & $4.4 \pm 0.6$ & $2.0 \pm 0.5$ & $3.2 \pm 0.4$ \\
\hline $21-24$ & $2.1 \pm 0.5$ & $1.3 \pm 0.5$ & $1.7 \pm 0.3$ \\
\hline $25-29$ & $2.0 \pm 0.4$ & $1.4 \pm 0.5$ & $1.8 \pm 0.3$ \\
\hline $30-39$ & $1.5 \pm 0.3$ & $0.9 \pm 0.2$ & $1.2 \pm 0.2$ \\
\hline $40-49$ & $1.8 \pm 0.3$ & $1.0 \pm 0.2$ & $1.4 \pm 0.2$ \\
\hline $50-59$ & $1.7 \pm 0.3$ & $1.1 \pm 0.3$ & $1.4 \pm 0.2$ \\
\hline $60-64$ & $2.2 \pm 0.8$ & $1.0 \pm 0.5$ & $1.7 \pm 0.5$ \\
\hline $65-$ & $1.3 \pm 0.8$ & - & $0.9 \pm 0.6$ \\
\hline
\end{tabular}

Koko työtön

työvoima $2.0 \pm 0.1 \quad 1.1 \pm 0.1 \quad 1.6 \pm 0.1$

Edellä todettu työintensiteetin aleneminen nuorimmissa työikäisissä ikäluokissa osoittaa ilahduttavaa kehitystä, jonka tulisi edelleen jatkua. Mahdollisimman monen työkuntoisen ihmisen elämässä pitäisi voida entistä selvemmin erottaa se aika, joka on valmistautumista ammattiin. Suurten ikäluokkien paineen edessä koululaitoksemme laajuuden sanotaan kuitenkin lähivuosina käyvän riittämättömäksi. Valtakunnansuunnittelutoimistossa suoritetussa tutkimuksessa on nimittäin todettu, että vaikka eri koulumuodot ovatkin voimakkaasti laajentumassa, ei tämä ole kuitenkaan riittävää, vaan koulujen ulkopuolelle jää yhä kasvava nuorisojoukko. ${ }^{3}$ Koulujen perusverkoston jatkuva tihentäminen olisi siten välttämätöntä. Tämän rinnalla harjoitettavaan työllisyyspolitiikkaan läheisesti liittyvänä pitäisi voida jatkaa ja kehittää meillä menneinä työttömyysvuosina käytettyä ammattikurssitoimintaa lähinnä alkutuotannon piiristä tulevan ammattitaidottoman nuoren työvoiman kouluttamiseksi.

3 Ennakkotietoja ns. suurten ikäluokkien koulunkäynnin mahdollisuuksia ja tarvetta valaisevasta tutkimuksesta. Valtakunnansuunnittelutoimisto. 1961. Moniste. 